IJAMSR 2 (1) www.ijamsr.com CrossRef: https://doi.org/10.31426/ijamsr.2019.2.1.116

\title{
Contribution of Allama Iqbal to Muslim Educational Thought
}

\author{
Ajaz Ahmad Telwani \\ Ph.D. Scholar, Dept. of. Education, Iqbal Institute of Culture and Philosophy, \\ University of Kashmir , Kashmir, India \\ Email: ajazahmad1127@gmail.com
}

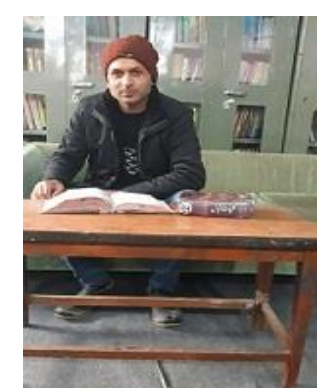

AJAZ AHMAD TELWANI

\section{Keywords:}

Muslim Education, Islam, Khudi, Ijtihaad, Self-realization.

\begin{abstract}
A B S T R A C T
During the British rule over India, the Muslim education gradually lost its shine that it had during the Muslim period. It received a major setback and suffered a further reversal with the introduction of Modern education. Allama Iqbal had intensely felt the progressive decline of the Muslim society in general, and the Indian Muslims in particular, and therefore he was deeply concerned with the problem of Reconstruction of Religious thought in Islam. He advised all Muslims to restore Islamic values, in theory and practice in order to bring about the much needed Islamic Renaissance. He worked throughout his life for Islamic solidarity and Universalism and tries to apply academic philosophical standards to Islamic thought. He was not satisfied with the results of Nadwatul Uloom Lucknow and Aligarh Muslim University because they either failed to satisfactorily incorporate modern subjects or were too far from Islamic studies to train genuine Muslims. He advised Muslims to get and aspire for education which will enable them to compete with other nations of the world. He exhorts the Muslims to create a new world order by integrating science with religion in their educational system so that it gives a spiritual interpretation of the universe which is one of the basic needs of humanity today. Allama Iqbal's contribution to Islam and Muslim are unparalleled in their characteristics and his followers interwove the practicability on the basis of his ideas. Iqbal's most important contribution was his restoration of a conscious energetic spirit of Islam. The present study is an attempt to study Iqbal's educational thought and his contribution to Muslim education with respect to its aims, curriculum, methodology, role of teacher and women's education. The researcher concludes with the idea that we need reform in our educational system in order to teach the true spirit of Iqbal and motivate youth to play their role in the society.
\end{abstract}

Citation: Ajaz Ahmad Telwani (2019). Contribution of Allama Iqbal to Muslim Educational Thought. International Journal of Advanced Multidisciplinary Scientific Research (IJAMSR ) ISSN:2581-4281, 2 (1), January, 2019, \# Art.1116, pp 33-46 
IJAMSR 2 (1) www.ijamsr.com CrossRef: https://doi.org/10.31426/ijamsr.2019.2.1.116

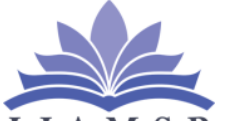

I J A M S R

\section{International Journal of Advanced Multidisciplinary Scientific Research (IJAMSR) ISSN:2581-4281}

\section{Introduction}

Islam has completed 1400 years of its history and has recently entered in the $15^{\text {th }}$ century. Islam attaches immense importance to the acquisition and extension of 'Ilm' or knowledge. Muslim education is unique from other types of educational theory and practices largely because of all encompassing influence of the Quran. Education in the context of Islam is regarded as a process that involves balanced growth of the total personality of man through the training of man's spirit, intellect, rational self, feelings and bodily senses. History has witnessed the emergence of Islam, its rapid and dynamic spread across the globe. India was soon acquainted with this religion after successive Muslim invasions, especially during the medieval period. Muslims rule over India for about 800 years. It was during the medieval period Muslim ruler's especially Mughals started a new system of education popularly known as Muslim education. The Muslims establish Maktabs, Madrassas and Mosques for giving education. They considered education as the greatest of all gifts. They believed that it is better to educate one child than to give gold in charity. Muslim education in India made progress both in the early Muslim period and in the Mughal period. But the kings who did great service for education are Faroz Shah Tuglaqk (1351-1388 AD), Sultan Sikandar (1489-1517 AD), Akbar (1556-1605 AD) and Aurangzab (1658-1707 AD).

The Muslims constitute the largest minority in India. They were the rulers of the country before the Britisher's took over from them. With the disintegration of Muslim rule particularly after the unsuccessful attempt of 1857 , the Muslim education gradually lost its shine that it had. It received a major setback and suffered a further reversal with the introduction of modern education. The British described the Indian system as 'Indigenous system of education'. The Muslims were fears that their mode of life may get diluted due to the Western system of education introduced by the British so they launched Madrassa moment by establishing DarulUloomDeoband (1866), Mohammedan Anglo-oriental college (1875) (which later becomes Aligarh Muslim University in 1920) and NudwatulUloomLucknow (1894) with a view to provide Islamic knowledge as well as scientific knowledge to the Muslims. The most prominent intellectuals during the 19th and 20th century who identified the source of Muslim weakness and initiated a reformation to boldly redefine or reconstruct Islamic belief and thought were Jamal-al-Din al-Afghani (18381897) and Mohammad Abduh (1849-1905) in the Middle East and Sir Syed Ahmad Khan (1817-1898) and Mohammed Iqbal (1877-1938) in the South Asia. They wanted to bring Islam in harmony with science and reasoning i.e., modernization of Muslim education. These persons belong to the same race and period and were included among freedom lovers and freedom fighters (mujahideen). We acknowledge their worth, but it is restricted to being tireless Muslim mujahids who struggled for years to expel Britain from their country and fought very hard for it. But Iqbal is greater than all of them and the greatness of his work cannot be compared with any of them. As Iqbal's problem is not confined to India it is the problem of the Islamic world and the East. The late Quad-I-Azam made the following remarks about the Iqbal's contribution:

Iqbal was a remarkable poet of worldwide fame and his work will live forever. His service to his country and the Muslims are so numerous that his record can be compared with that of the 
IJAMSR 2 (1) www.ijamsr.com CrossRef: https://doi.org/10.31426/ijamsr.2019.2.1.116

\section{International Journal of}

I J A M S R

Advanced Multidisciplinary Scientific Research (IJAMSR) ISSN:2581-4281

greatest Indian that ever lived..... Although a great poet and philosopher, he was no less a practical politician. With his firm conviction and faith in the Ideals of Islam, he was one of the few who originally thought over the feasibility of carving out of India an Islamic state in the North-West and North-East zones which are historical homelands of Muslims.

Iqbal had intensely felt the progressive decline of the Muslim society in general, and the Indian Muslims in particular, and therefore he was deeply concerned with the problem of Reconstruction of Religious thought in Islam. In his philosophical works, Metaphysics and Reconstruction, Iqbal examined Islamic thought in all its aspects, and attempts to present the Quranic interpretation in the light of twentieth century requirements in a coherent form. In his poetic works, he went further to elaborate a set of concepts-Self, Community, socio-political implications of the Islamic doctrine of Tawheed, Islamic democracy, economy and other relevant concepts. Iqbal offered an Islamic ideology as an alternative to all contemporary ideologies. He advised all Muslims to restore Islamic values, in theory and practice in order to bring about the much needed Islamic Renaissance. The landmark contribution of AllamaIqbal to the cause of Muslims and Islam was the first formal presentation of the Pakistan plan in his presidential address to the all India Muslim League in Allahabad in 1930. Iqbal is not only a renowned thinker on education; he, in fact practiced his thought.
Iqbal was not the name of an individual, but an institution, an age and above all a champion of Muslim Renaissance. He worked throughout his life for Islamic solidarity and Universalism. He is the only thinker of recent times who tries to apply academic philosophical standards to Islamic thought. He was not satisfied with the results of NadwatulUloomLucknow and Aligarh Muslim University because they either failed to satisfactorily incorporate modern subjects or were too removed from Islamic studies to train genuine Muslims. He advised Muslims to get and aspire for education which will enable them to compete with other nations of the world. His whole educational thought is based on his concept of Self or Khudi. Iqbal's greatest service to the Muslims was that he reawakened them to face the hard facts and problems of their religion, social and political life in the light of the genuine spirit of Islam itself. Thus the intellectual vision of Iqbal was shaped by the Islamic and Western traditions. The East and West, Orient and Occident met in the confluence of his thought and philosophy and created in him a universal vision embracing the entire humanity. Iqbal strongly felt that the crisis of the contemporary world was caused by the dominant ideology of the modern Western materialistic civilization. According to him Secularism, Materialism and Godless humanism are the root causes of the crisis faced by the human society. It is in this context, that Iqbal's concept of dignity of man and the sanctity of human personality and freedom assumes significance. Iqbal through Zarb-e-Kalim wanted to rescue Muslims from the ills brought by the modern civilization, just as Moses had rescued the Israelis.

While reviewing the literature related to the present problem, it has been found that Iqbal's ideas on education are mostly scattered in his poetic collections, 
lectures, essays and letters. This has deterred many educational researchers from working on Iqbal because it becomes a stupendous task to weave a system out of this scattered material. AllamaIqbal is regarded as one of the greatest personalities of the modern Muslim world. The Western and the Eastern scholars and intellectuals have recognized profundity and versatility of his thought. His thought is very fresh and it has relevance to the modern time because the problems which were being faced by Iqbal are still there and the imperialist designs against Islam and Muslims against which Iqbal fought relentlessly persist. Iqbal's philosophy of time, views on khudi, science and religion, ijtihaad, education and vitalist vision are the areas which can be probed in light of modern developments worldwide. Hence Iqbal's thought is multidimensional, profound and appealing. It manifests many thought sub-categories in it like political, legal, social, psychological, historical, educational, epistemological etc. Iqbal's contribution to these fields is immense and it is not possible to touch all these fields at a time, Hence an effort has been made in the present study to formulate concisely Iqbal's educational thought and his contribution to Muslim education.

\section{Iqbal's Educational Thought}

Briefly, education, according to Iqbal, is a means to an end and not an end itself. The end of educations being Islamic Ideology and Culture. It is through education that a culture perpetuates itself. Since every system of education basically consists of social ideals, norms and values and is based on its specific culture. Iqbal exhorts us not to imitate other nations. Iqbal believed that the basic aim of education is the self-realization, which means consciousness of divine attributes which constitutes the very essence of man. Iqbal's whole thought is based on Self or Khudi. Khudi is that unit of intellect which is self-knowing and self-cognition and is conscious of its seat and its goals. Khudi here does not mean mind or discretion, but it is something which has to be kept well in mind or on account of which man has mind and discretion. The same faculty in man calls himself ' $\mathrm{I}$ ' on account of being self-knowing or selfcognizant. So Iqbal calls it ana, or Ego, or 'I'. In Iqbal's view this khudi passes through three stages in its evolution i.e., A sense of one's own existence, a sense of existence of others and a sense of the existence of God. Thus Iqbal's philosophy is the philosophy of egohood and said that education begins from a sense of ego. Ego will undergo a process of evolution and is always striving to achieve perfection. Perfect ego according to Iqbal is called perfect man and that is the purpose of education. As Iqbal says;

\section{Elevate yourself to such heights that before destiny (intervenes)}

God himself may ask his slave, tell! What doeth thou will

Iqbal lays unprecedented stress on the development of self in man as well as in society. In fact he regards this failing of the Muslims as the primary cause for their humiliation in the world. The primary cause of the downfall of Muslims, in his opinion was religious dogmatism, which had debased Islam and had obstructed its evolutionary process. The Muslin theologians were laying too much stress on rituals and had completely neglected spiritual advancement. According to Iqbal Muslims in the past had progressed as a result of their

${ }^{\dagger}$ Ishrat, 2003. Hundreds Years of Iqbal, p. 647 
IJAMSR 2 (1) www.ijamsr.com CrossRef: https://doi.org/10.31426/ijamsr.2019.2.1.116

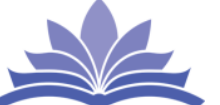

I J A M S R

International Journal of Advanced Multidisciplinary Scientific Research (IJAMSR) ISSN:2581-4281

rational approach and deteriorated by the neglect of it. Iqbal is of the view that Western culture of the medieval period had heavily borrowed from the Muslim culture which had helped them to make great advances in life. Iqbal thus advocated a re - interpretation of Islam in the light of that spirit of the Muslim culture which was exhibited by the classical Islam in the medieval period. $\mathrm{He}$ is fully mindful of the fact that magian crust has grown over Islam and considers Ijtihad as the key to Muslim recovery to bring the Muslim Ummah in line with the other modern societies of the world.

He says: It is Ijtihad which, as a principle of movement in Islam lends mobility to its legal system. The emergence of the four popular schools of Fiqh reflects ceaseless efforts on the part of the interpreter to have updated the law to meet the requirements of their times. The ensuing generations were, therefore, justified to do the same to meet the challenges of their times.

In order to meet the challenges of the modern world, he advocates a dynamic approach, which is multidimensional in character. Realizing the power which education has to transform societies, he proposes acquisition of knowledge of the Muslim societies as the key to the solution of a lot of problems. It is the scientific knowledge which gives man the greatest confidence in himself as it is only through knowledge that his powers to acquire mastery over the universe are extended. It enhances his creative abilities and makes him a worthy partner in the creative activity of God.

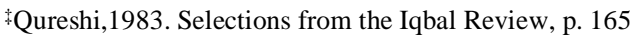

During his stay in Europe, he realizes the real meaning of life. He said my forefathers spent their lives in search of God, But I am spending my life in search of man. Iqbal's philosophy is an extension of the tradition of Islamic thought. According to him, the ultimate reality is only one. It is self-directing, self conscious energy and is essentially a spiritual. The universe is its manifestation and there is no dichotomy between the ultimate reality and its manifestation. His philosophy converges on the man, his nature, his relationship to this physical world and hereafter, how the individuality of man develops. Iqbal's educational philosophy reflects from his general philosophy of life; his ideas about knowledge, man and his nature. Iqbal's concept of life and the universe was that of having a soul in motion. Motion or dynamism is the basic component of his philosophy. Iqbal's philosophy or thought is creative as well as synthesizing. It is creative in the sense that he showed a new direction to his period by his philosophy of khudi and the theory of dynamism. It is synthesized in the sense that, looking critically into the thoughts of the Eastern and Western philosophers in the light of his creative theory, he established harmony between them and gave his own opinions. Hence the core of Iqbal's educational theory puts greater emphasis on the complete, harmonious development of individual personality. He believed that education should help an individual to attain complete manhood, so that all his powers may be developed to the fullest extent for his own individual perfection as well as the perfection of the human society in which he was born.

\section{Aims of Education}

Educational aims are primarily a phase of values. They are conscious or unconscious value judgments. These judgments involve thinking in Metaphysis and 
IJAMSR 2 (1) www.ijamsr.com CrossRef: https://doi.org/10.31426/ijamsr.2019.2.1.116

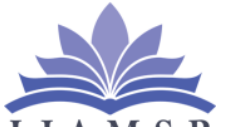

I J A M S R

International Journal of Advanced Multidisciplinary Scientific Research (IJAMSR) ISSN:2581-4281

Epistemology. Educational aims take their roots from philosophy. Iqbal's philosophy is the philosophy of self. A weak person in Iqbal's philosophy will become easily suppressed by the powerful and it is the highest crime in philosophy of Iqbal which appears in his highly writings. In his view, "a strong will in a strong body is the ethical ideal view of Islam." Criticizing the educational system of his times he says very emphatically:

I venture to say, that the present system of education in this country is not at all suited to us as a person. It is not true to our genius as a nation, it tends to produce a un-Muslim type of character, it is not determined by our national requirements, it breaks entirely with our past, and appears to proceed on the false assumption that the ideal of education is the training of human rather than human will.s

The aim of Education, according to him, is to develop the personality by activity, creativity and originality, with a view to preparing man for the conquest of the material forces of the Universe and further the achievement of spiritual heights of man. He viewed the cultivation of the individuality as the highest goal of all social and educational efforts. For this, valuable purpose religious and moral education is essential. He writes in a letter to K.G Saiyidain,

By Ilm I mean that knowledge which is based on sense. This knowledge yields physical powers which should be subservient to deen (i.e. the religion of Islam). If it is not subservient to din then it is demonic, pure and simple..... It is incumbent on Muslims to Islamize knowledge.
"Abu Lahab should be metamorphosed into haiyder. If Abu Lehab becomes Haiyder-e-Karrar, or in other words if it (i.e. knowledge and the power it yields) becomes subservient to the din, then it would be an unmixed blessing into mankind. ${ }^{* *}$

\subsection{Development of character}

Constructing the good character of the man was much emphasized in Iqbal's educational philosophy. Good character is one of the main elements or constituent of self-realization which is the result of training and education. For good character it is essential that man should possess three qualities to carry out the purpose of life which described by Iqbal as courage, tolerance and Faqr (humanity). To cultivate such lofty qualities in the pupil is the real function of education as per the belief of Iqbal. For the development of good character, Iqbal raise voice against the fear or weak personality by realizing the development of individuality. Courage is essential nourishment for its development. Life is continuous battle and without courage and constant efforts selfrealization is impossible. We learn the Lesson of courage from the daily work of ant. How an ant carries a grain of rice much bigger than itself without any fear. With this load how an ant climbs up a wall, if the grain falls down the ant comes down and lifts the grain again without losing its courage and tries until it succeeds in taking the grain up the wall. Courage is the greatest attribute possessed by man, which increases the strength for continued struggle. No one can achieve greater results in life without courage. Noble Qur'an teaches us that "there is nothing for man except what he tried his 
IJAMSR 2 (1) www.ijamsr.com CrossRef: https://doi.org/10.31426/ijamsr.2019.2.1.116

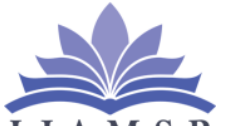

I J A M S R

International Journal of

Advanced Multidisciplinary Scientific Research (IJAMSR) ISSN:2581-4281

efforts shall be seen and rewarded to fullest extent". AllamaIqbal firmly believed that today's young generations are tomorrow's leaders, governors, and teachers and so on about the future. So younger generation needs to understand that being weak spirited is not becoming a part of their personality. If one shows fear except the fear of God, then life loses all purposes. Iqbal maintains that fear becomes the cause of individual weakness and the source of all kinds of corruption in the individual character. He believes that the courage is essential for the proper development of individuality. Iqbal maintains that courage man is one who is able to overcome and combate all obstacles and no submission to the forces of evil or to desire to give an accept to conviction. Iqbal addresses upon the younger generation to live courageously so that they will become the best architects of their own destiny. He constantly refers to the Quranic verses Verily God will not change the condition of people till they change what is in themselves. (Surah $\mathrm{Al}-\mathrm{Ra}$ 'd). The second quality of a good character is tolerance. It is very essential element for the development of dignity of the human beings. Iqbal also considered it is an important ingredient of self-realization and also for the progress of society.

Faqr is the third most important quality of good character in Iqbal's philosophy. AllamaIqbal advocated the need for developing Faqr among students. He felt that man confronted with a lot of problems due to developing materialistic outlook and people is thought in terms of loss and profit which is referred to as statistical thinking. Such thinking is the main cause that the spirit in man turns into stone and loses their humanity. Therefore Iqbal felt the need to prepare an ideal student, i.e. (Mard-e-Momin). Iqbal'sMard-e-Momin is one who detaches himself from the material things and is always busy in search to learn higher values so that he could accomplish his vision by thwarting every attack of evil. Iqbal wants to reconstruct the world in the name of the Lord and put to stress to develop faqr among students and leading a life of voluntary and self-denial.

\subsection{Development of Human personality or Outlook}

In Iqbal's concept, the creation of a good personality in an individual also meant the creation of a good man with a good character. As such, in the endeavor to produce individuals of exceptional character and personality, schools and institution of learning should not confine learners to the four walls of the classroom. Iqbal believed that, it is through the theoretical and practical approaches in learning that the personality of an individual will grow in a more enriching manner. According to him, if education is not permitted by human outlook, there will be no salvation for mankind. Today man is faced with the problem of moral degradation through the miss used intelligence. Human's have become the most violent being in this world, they have succeeded to some extent, but in doing so have paid them a terrible price. They have sacrificed their peace of mind for material comfort and power. Iqbal's concept of Mard-e-Mumin indicates going beyond worldly pleasures. The cause of inner happiness does not depend merely upon the satisfaction of physical appetites and passion. Even if we have all the worldly pleasures, we still cannot be happy. Real satisfaction of life cannot be defined solely in terms of wealth and power. Therefore Iqbal's Educational philosophy, spiritual in nature is a basic condition to maintain humanity among people otherwise humanity itself is in danger of being wiped out. Iqbal gives importance to religious institutions where people learn and develop a humanitarian outlook. Religion means the integration 
IJAMSR 2 (1) www.ijamsr.com CrossRef: https://doi.org/10.31426/ijamsr.2019.2.1.116

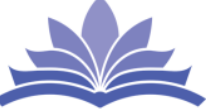

I J A M S R

International Journal of Advanced Multidisciplinary Scientific Research (IJAMSR) ISSN:2581-4281

and unity which holds the mankind as a whole. The qualities like kindness, charity, social service, and goodness are known to be the true mark of a good human being. Iqbal elevates man's role and his position in a very dignified manner. His educational philosophy wishes an ideal student which is not only the central of the world, but is also able to do God's assistance in the creation, refinement and perfection of the universe which is still imperfect.

\section{Delve in thy soul to get the secrets of life Be friend of thyself if not mine \\ Learn again the lessons of truth, justice and bravery \\ You are to be entrusted with the world's leadership ${ }^{\dagger \dagger}$}

\subsection{Ideal-oriented Education}

Education should be ideologically oriented and according to Iqbal, education is a means to an end and not an end in itself. The end of education being an Islamic ideology and culture. It is through education that a culture perpetuates itself. Since every system of education basically consists of social ideals, norms and values and is based on its specific culture, Iqbal exhorts us not to imitate other nations and says:

Seek not the bounty of the glass blowers of the West

Make your own cups and goblets from the clay of India ${ }^{\text {th }}$

Education must instill those beliefs and ideals for which the nation stands. Preservation and promotion of the religion and culture of the people should be the purpose of education. Iqbal's idea about education would reveal that he had tried to reconnect the broken links of the educational tradition of Islam. His chief contribution to the educational ideology is the emphasis on Din, which includes science. Science should not be considered merely knowledge gained by observation and experimentation, but it should embody all knowledge based on truth. According to him culture and ideals of society should be the guiding factors of our education and wants to establish a balance between an individualism and collectivism. He regards the development of individuality as the fundamental value, but does not ignore at the same time the growth of social science and collective responsibilities. Therefore an ideal system of education will always aim at the establishment of balance between the developments of individuality and social consciousness of the individual. He therefore very aptly remarks

Individual exists by virtue of his social contacts. He is nothing without that association.

He is like a wave in the river and has no existence outside it ${ }^{\$ \S}$

His conception of individuality is therefore unique and is altogether different from the conception held by the traditionalists. The individual of his conception is thorough community minded man. Iqbal holds that life is reality its basic root is self and for its development man must firstly create desire for struggle in order to achieve the knowledge to create love for human welfare. The Iqbals provide opportunity for the spirit of man to test its power and potentialities so that he will become able to overcome his problems. A few quotations from his Urdu and Persian verses will suffice to prove his contention.
${ }^{\dagger}$ Khalil, 2015.AllamaIqbal's Bang-I- Dara. P 421

\$Umar, 2006.Iqbal and Modern Era, p. 64
$\S \S$ Beg, 1961. The Poet of the East: Life and works of Dr. Sir Mohammed Iqbal, p. 254s 
IJAMSR 2 (1) www.ijamsr.com CrossRef: https://doi.org/10.31426/ijamsr.2019.2.1.116

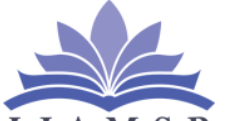

I J A M S R

\section{International Journal of Advanced Multidisciplinary Scientific Research (IJAMSR) ISSN:2581-4281}

\section{Curriculum}

Today the educational curriculum planned by the World bank and the IMF is being adopted without any sense of critical analysis in the third world countries and it is in this sense phrases like marketable courses, job market are being used. Iqbalcriticises the generation which has been brought up under the influence of an alien system of education which was opposite to our culture, distasteful to our civilization, and affronting to our tradition. Iqbal wanted a life centered curriculum, realistic and related to the needs and demands of the developing individual and also reflecting the norms, values and aspiration of the society. He stressed curriculum should be framed in such a way that prepares a child to become an ideal man. Ideal student can be achieved only when he grooms to become fully armed and empowers to face the challenges of life, to channelize their efforts and apply their intelligence to solve the microscopic puzzles of nature, and be able to refuse to make compromises with falsehood. So that all expenditures lead a man towards self-realization. Iqbal emphasizes that curriculum which awakens conscious behavior of the child, which is higher than animal consciousness. Therefore Iqbal put stress on the teaching of religion as a core of curriculum.

Iqbal asserts that religion is not a departmental affair, it is neither mere thought, nor mere feeling, nor mere action, and it is an expression of the whole man. Jacques Martain an educationist follower of Bergson's philosophy of life also accepts vital position of religion in education. According to him, the complete and the integral idea of man, which is the prerequisite of an education can only be philosophical and religious idea of man. I say philosophical because this idea pertains to the nature and essence of man, I say religious because of the existential status of this human nature in relation to God. Iqbal's educational philosophy does not emphasize to develop literate uneducated but wishes to develop literate educates, having a heart with feeling and a life with emotions. They are humans with courage, tolerance, faqr, creativity, originality, free will, resourcefulness, dominance, self control and self confidence. They develop such qualities only under the influence of religious education. Religious education sets up high ideals and attempts to plant seeds of nobility in the hearts of people. The teaching of religious subject prepares man for the burden of great responsibility to convert man into Mard-I-Momin and leads him toward righteous and virtuous life.

Iqbal was in favor of that curriculum which reflects the norms and aspiration of society. As we know before Iqbal leaving for Afghanistan in 1933 for Educational planning of that country, he issued the following statement;

Personally, I believe that the complete secularization of education has not produced good results. Nor is there any absolute system of education. Each county has its own needs and its educational problems must be solved in the light of those needs ${ }^{* * *}$

Iqbal's writings and speeches clearly indicate that Iqbal does not wish a man of an imitator or adaptor of the culture of others which results in the heights of excellence will reduce to the level of beasts. Therefore, Iqbal gives much importance to the teaching of history. Teaching of history provides the solution of contemporary problems by tracing of changes in

\footnotetext{
${ }^{* * * *}$ Masoodi, 2007. Educational Philosophy of Iqbal, p. 80
} 
thoughts, attitudes thinking process and so on. According to Iqbal, there are three sources of knowledge mention in the Qur'an and history is one of them, which occupy a definite place in it (Qur'an). The thorough understanding of nations and communities are well reflected from the mirror of history. For the economic upliftment of underdeveloped societies, Iqbal empathetically stresses the incorporation of technical education in the curriculum. In the educational institutions and also even in traditional institutions up to intermediate level, Iqbal recommends science, mathematics, philosophy and economics. At university level, he suggests Muslim art and architecture, literature and history, but in the selection of subjects, Iqbal strongly favors the interest and capability of the student.

\section{Methods of Teaching}

Education is concerned with the problems of individual and society, hence the subject and method of education must be in consonance with the natural tendencies of a child's mind, his instincts and emotions. While educating the child the teacher must take into consideration his dominant psychological trends and the stage of development of his personality. The psychology of development is of utmost importance for methodology. As regards to methodology of teaching, Dr. Sir Mohammad Iqbal contributes in a very significant way. The methods of teaching of Iqbal's educational philosophy are based on the principles of psychology and sociology that gives adequate scope for active participation of the adjacent. In his educational philosophy child development occupies a central position in the learning process rather than books. Children should be providing constant opportunities to explore their potentials. Iqbal believed the potential qualities are developed in accordance with the child's interest, abilities and attitudes. So that by his own efforts, he creates his own values which equip him to face all the problems of life. Therefore, he wanted the schools to bring up free, daring and creative individual. For this purpose he made certain principles of teaching which includes:

\subsection{Activity, research and originality.}

Iqbal advised the Muslims to get and aspire for an education which will enable them to compete with other nations of the world. He stressed the point that they should not remain passive, but should actively participate in different constructive activities so as to make their individuality sound in order to make their nation strong. His philosophy of action declared that this world, paradise and even Hell, are all related to action and movement. The man by his nature is neither like light or Angels nor like fire or the devil, but their actions and deeds make them so. In Bal-i-Jibreil, his poetry explains learning by doing is the method of teaching. The movement gives color and meaning to life, movement is reality, the rest is illusion.

Again he says,

On this road, halt is out of place.

A static condition means death those who on the move, have gone ahead,

Those who lagged behind for a movement having crushed ${ }^{\dagger+}$

\subsection{Observation and Experience:}

It is well known fact that experience and observation are corner stone's for constructing the building of knowledge. Interaction is very important to the

\footnotetext{
††Iqbal, 1993.Kuliyat-i- Iqbal, p.146
} 
IJAMSR 2 (1) www.ijamsr.com CrossRef: https://doi.org/10.31426/ijamsr.2019.2.1.116

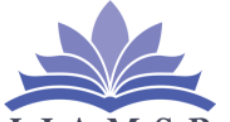

I J A M S R

\section{International Journal of Advanced Multidisciplinary Scientific Research (IJAMSR) ISSN:2581-4281}

environment, man will not able to construct it without knowledge. According to child psychology a child can construct the building of knowledge about animals only by interacting with them, He learns how they walk, what sounds they make and continually adds to his knowledge until he is able to attain understanding and beliefs about animals. Observation and experience method allow pupil to grasp multiple perspectives, opinions and introduction of new ways to approach the task. Iqbal is a poet, philosopher and his poetry clearly put emphasis on observation method as he says,

Open the eyes look at the earth and sky Look at the sun, rising gloriously in the east These winds and clouds, these silence spheres, These dooms of the skies,

Thy spark has a luster of the blessing sun A new world is latent in thy creative skill

Here Iqbal invites man for the elevation of selfrealization and suggest education for the development of sense organs of pupil unhampered.

For teaching, he approved of only those methods, which involved self-activity, learning by doing, problem solving, purposeful work experience where the student utilizes the resources of the environment, adopt appropriate means to realize the goals and relies on his own groping with intelligent efforts and overcome their difficulties.

\section{Role of Teacher}

The educational system rotates around the teacher. It is not possible to visualize any educational program without a teacher. Teachers are the life of the society. They are not only instructors but also the teachers of manners and patrons of human beings. Iqbal was an idealist and wished that teacher should become the spiritual father of his pupils. In view of Iqbal teacher should not force their spiritual experiences on to the mind of the student, but properly guide their mind to get experience according to their innate abilities. They assist the student to develop as per their own nature and It is the responsible job of teacher to modify the personality of the pupil for the welfare of the society or, in other words teacher as a custodian of the society and the architect of the nation.

In the teaching learning process, Iqbal considers teacher as a central and unique figure in shaping student's personality towards moral development. In pragmatic approach Iqbal considered teacher as the only instrument who is able to create the situation where the students can identify their problem and encourage them to perform experiments and solve the problems step by step in order to think and act for themselves, so that they learn by their own experience. The activities make the student creative and help them to acquire the capacity to adapt themselves to new situations. Iqbal was not in favor of implementing rigid disciplinary rule and it is the function of teacher to arrange the activities in such a way which appeal to the natural interests of the child, then the problem of indiscipline cannot arise and they become able to realize their innate abilities. Iqbal said, 
IJAMSR 2 (1) www.ijamsr.com CrossRef: https://doi.org/10.31426/ijamsr.2019.2.1.116

\section{International Journal of}

I J A M S R

\section{Advanced Multidisciplinary Scientific Research (IJAMSR) ISSN:2581-4281}

He creates new lives of insight

And brings a garden to bloom in the desert;

We are all emotionally inspired by his fire;

Otherwise we would be poor creature of water and clay;

He gives a new form to the naked intellect;

And invests its poverty with riches ${ }^{\text {ss }}$

\section{Women Education}

Iqbal does not criticize women's education, but, in this respect, he follows the famous proverb that the hands that move the cradle, rule the world. Education is not only essential for men, but also for women. He asserts that if a woman is not given due status and, if not protected from the ups and downs of life she can cause destruction to the whole universe. Real advancement cannot be possible without women education in any field of human life. Women's education is not only essential for the development of society, economic prosperity and national solidarity, but also for the proper development of children's. Kothari education commission (1964-66) has laid notorious remarks by giving greater importance to woman's education. "For the full development of human resources, the improvement of human beings and for molding the character of children in the most impressionable years of infancy, the education of woman is of greater importance than men." Pt Jawaharlal Nehru also emphasized "if you educate a boy you educate only one person, if you educate a girl you educate the entire family. Iqbal's views on female education are apparent in his poems such as 'The Ideal Woman' and 'The Glory of a Woman'. To him the creation of woman and their presence is a great blessing of God, since a woman is an inspiration of life. He pays great tributes to a woman, although she had not produced high intellectual and scientific works, but she can and has given birth to great personalities.

In view of Iqbal, the woman is a symbol of nobility, softness, and lover of truth. Love is an essential factor in stabilizing of humanity and self-awareness (khudi) in human society as he says. The focal point of luminous light, Iqbal is of the opinion,

Known by the name of the self (Khudi) Beneath our dust, in fact, is the spark of light itself.

But love certainly becomes more lasting and more living

More burning with desire, more radiating growing

Love adds fuel to fire of the essence of the self Khudi

It opens up hidden avenues of progress for the self khudi

The nature of the self-obtain its fires store from love

It learns elimination from the light of love

Love is at the very root of peace of war in here * $^{* * * *}$

Iqbal had a belief that woman is an incarnation of love and it gets cleared from his poetry when Iqbal cried at the death of his mother (Imam Bibi). Iqbal himself is a good example in front of us; because he was brought up in the lap of affectionate mother. On the death of his mother, Iqbal expresses his sorrow feelings of missing her love as he says;

Who would wait for me anxiously in my native place?

Who would display restlessness if my letters fail to reach.

I will visit thy gave with this compliant

- Who will now think of me in mid night prayers? 
IJAMSR 2 (1) www.ijamsr.com CrossRef: https://doi.org/10.31426/ijamsr.2019.2.1.116

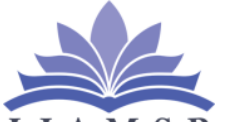

I J A M S R

\section{Advanced Multidisciplinar
fe, the love sorrowed me with devotion}

When I become fit to serve then thou has departed ${ }^{\dagger+1}$ The above verses explain that Iqbal missed the love and guidance of her affectionate mother, who always take care him in every aspect of life. Therefore Iqbal was in favor of an education for women that will inculcate in them feminine characteristics, and will enable them to fulfill the duties and responsibilities in the future. Furthermore, religious education should form an important part of their education, and it is not only education, but the protection provided by the men that can really give her security and support. Iqbal considers the education of woman more important than the establishment of an exemplary Dar-ul-Ulum. Therefore, he stated that moral, spiritual and religious education should be imparted to women as she is the first teacher of her child and is responsible to teach her child regarding courage, tolerance, faqr, desire, freedom, love and so on are very essential factors for the development of self- realization.

\section{It's due to your care that I got fame in the world \\ My forefather's abode became a place of honor tht $^{\text {th }}$}

According to Iqbal, the family is the place from where the child learns the norms and trends of the society. The child's parents mould their child's personality. That is why woman occupies a dominant place in its upbringing. Woman is the true builder of the nation. Education is always given according to the needs and aspiration of the nation. Women are naturally inclined towards religion with their minds and hearts in their control. Therefore, it is necessary that we should provide them such opportunities in which they will receive a true Islamic education, because it is obligatory for the preservation of an Islamic society. He says in Zarb-iKalim (1936):

\section{The whole universe is colorful due to her presence \\ The life's music is charming due to her tune.}

Annemarie Schimmel, who is an expert in the studies on Iqbal saying the following words as a tribute to Iqbal's intellectual ability:

Of all the Muslim thinkers of the modern world, Iqbal is the greatest of all of them... I acknowledge Iqbal as one of the Muslim reformers who has managed to formulate a trend of thinking which is original and complementary. It is a trend that consolidates the Islamic civilization with the good part that comes from the Western culture $^{\S \S \S \S}$

\section{Conclusion}

Dr. Iqbal was seriously interested in the field of education and has contributed to the meaning and purpose of education content and significance which appears to be richer and fuller than what it was previously. His whole educational thought is based and revolves on his concept of Khudi, which he has given in his world famous book 'Asrar-I-Khudi' (the secrets of the self). Iqbal describes Khudi as an emotional unity or a bright thing of the conscience by which all human

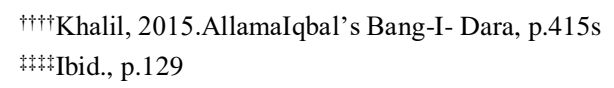

§§\&Usmani, 1991.Anniemariaschimmel,

OrientalispengagunJalaluddinAr-Rumi, p. 97 


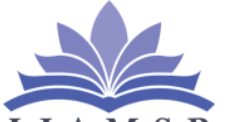

\section{International Journal of Advanced Multidisciplinary Scientific Research (IJAMSR) ISSN:2581-4281}

ideas and inspirations are enlightened. Iqbal therefore, proposes an educational system in which "Religion and Science are blended together". Iqbal in his early works; Asrar-i-Khudiand Rumuz-i-Bekhudi, encouraged Muslims to follow his prescriptions by harping on the themes of love, truth and freedom. He encouraged Muslims to embrace ideals of brotherhood, justice and service. Iqbal through Zarb-e-Kalim wanted to rescue Muslims from the ills brought by the modern civilization, just as Moses had rescued the Israelis. Iqbal was a pioneer of Islamic Renaissance in this subcontinent. He vigorously advocated the two nation theory and activated the Muslims of India in the name of Ijtihaad. Iqbal's educational thought emphasis such type of education which manifests the inspiration of Islamic ideology, aims at strengthening individuality, transforms the spirit of believing in the unity of God and prophesied with the faith that the last prophet Muhammad (SAW) is the ultimate role model, upholds the rational and empirical knowledge under the Divine revelation, cultivates values shaped under absolute knowledge and produces reflective, creative and responsible teachers who refrain from borrowed ideas and value free instructional practices. Dr. Maruf rightly says, the most important of all, and also the most original of Iqbal's contributions to philosophy of religion is his treatment of thought as operative in the mystical knowledge of God. Iqbal maintains that thought and intuitions are organically related. Hence we need reforms in our educational institutions to teach the true spirit of Iqbal and motivate youth to play their role in society. Continuous discourse and discussions on the teaching of Iqbal is needed. Allama Iqbal is exceptional today as he was exceptional in his life time. We need to apply the Iqbal's message to ourselves to deal with the problems of Muslims.

\section{References}

1) Bhat, A. R. (1996). Iqbal's approach to Islam- A study. New Delhi: Islamic book foundation.

2) Bhat, A. R. (1996). Iqbal's approach to Islam- A study. New Delhi: Islamic book foundation.

$$
\text { a. corporation. }
$$

3) Iqbal, S. M. (1936). Zarb-i-Kalim.Lahore

4) Iqbal, S. M. (1977). The Reconstruction of Religious through in Islam.Lahore: SH. Mohammed Ashraf.

5) Iqbal, S. M. (1993). KuliyatIqbal-Urdu. Aligarh: Education Book House.

6) Ishrat, W. (2003).Hundred Years of Iqbal. Islamabad: Pakistan Academy of Letters.

7) Jaffar, S. M. (1973). Education in Muslim India (1000-1800 AD). Delhi: Idarah-I Adabiyat-I Delhi.

8) Khalil, M. A. (2015). AllamaIqbal's Bang-i- Dara (trans).Srinagar: Gulshan Books Kashmir.

9) Masoodi, T. (2007).Educational philosophy of Iqbal. New Delhi: A.P.H. Publishing

10) Qadir, S. A. (2003). Iqbal- the Great Poet of Islam. Pakistan: Sang-e-Meel Publication.

11) Saiyid, M. H. (1962). Mohammed Ali Jinnah-.A Political study. Lahore: Iqbal Academy Pakistan.

12) Saiyidain, K. G. (2012). Iqbal's Educational Philosophy. Gurgaon, India: Shubli Publication.

13) Usmani, A. R. (1991). Anniemariaschimmel, orientalispengagumJalaluddinAr-Rumi, In Adzan, No. 20, p.97.

14) Vahid, S. A. (1964). Educational Thoughts and Reflections of Iqbal. Lahore: Sh. Mohammed Ashraf. 